\title{
Past and future interannual variability in Arctic sea ice in coupled climate models
}

\author{
John R. Mioduszewski ${ }^{1}$, Stephen Vavrus ${ }^{1}$, Muyin Wang ${ }^{2,3}$, Marika Holland ${ }^{4}$, and Laura Landrum ${ }^{4}$ \\ ${ }^{1}$ Nelson Institute Center for Climatic Research, University of Wisconsin-Madison, Madison, Wisconsin, USA \\ ${ }^{2}$ Joint Institute for the Study of the Atmosphere and Oceans, University of Washington, Seattle, Washington, USA \\ ${ }^{3}$ Pacific Marine Environmental Laboratory, National Oceanic and Atmospheric Administration, Seattle, Washington, USA \\ ${ }^{4}$ National Center for Atmospheric Research, Boulder, Colorado, USA
}

Correspondence: Stephen Vavrus (sjvavrus@wisc.edu)

Received: 11 May 2018 - Discussion started: 1 June 2018

Revised: 2 December 2018 - Accepted: 13 December 2018 - Published: 14 January 2019

\begin{abstract}
The diminishing Arctic sea ice pack has been widely studied, but previous research has mostly focused on time-mean changes in sea ice rather than on short-term variations that also have important physical and societal consequences. In this study we test the hypothesis that future interannual Arctic sea ice area variability will increase by utilizing 40 independent simulations from the Community Earth System Model's Large Ensemble (CESM-LE) for the 1920-2100 period and augment this with simulations from 12 models participating in the Coupled Model Intercomparison Project Phase 5 (CMIP5). Both CESM-LE and CMIP5 models project that ice area variability will indeed grow substantially but not monotonically in every month. There is also a strong seasonal dependence in the magnitude and timing of future variability increases that is robust among CESM ensemble members. The variability generally correlates with the average ice retreat rate, before there is an eventual disappearance in both terms as the ice pack becomes seasonal in summer and autumn by late century. The peak in variability correlates best with the total area of ice between 0.2 and $0.6 \mathrm{~m}$ monthly thickness, indicating that substantial future thinning of the ice pack is required before variability maximizes. Within this range, the most favorable thickness for high areal variability depends on the season, especially whether ice growth or ice retreat processes dominate. Our findings suggest that thermodynamic melting (top, bottom, lateral) and growth (frazil, congelation) processes are more important than dynamical mechanisms, namely ice export and ridging, in controlling ice area variability.
\end{abstract}

\section{Introduction}

Arctic sea ice extent has declined by more than $40 \%$ since 1979 during summer (e.g., Stroeve et al., 2012; Serreze and Stroeve, 2015; Comiso et al., 2017), primarily as a consequence of greenhouse gas forcing (Notz and Marotzke, 2012) but also internal variability (Ding et al., 2017). While this trend is greatest in summer, substantial losses are observed throughout the year (Cavalieri and Parkinson, 2012), resulting in an ice season duration that is up to 3 months shorter in some regions (Stammerjohn et al., 2012). Reduced ice area is accompanied by a greater fraction of younger ice (Nghiem et al., 2007; Maslanik et al., 2007a, 2011), which reduces the mean thickness of the basin ice pack (Kwok and Rothrock, 2009; Kwok et al., 2009; Lang et al., 2017). As a result, the estimated negative trend in sea ice volume $\left(-27.9 \%\right.$ decade $\left.^{-1}\right)$ is about twice as large as the trend in sea ice area $\left(-14.2 \%\right.$ decade $^{-1}$; Overland and Wang, 2013).

Output from many climate models suggests that the Arctic sea ice cover will not retreat in a steady manner, but will likely fluctuate more as it diminishes, punctuated by occasional rapid ice loss events (RILEs; Holland et al., 2006; Döscher and Koenigk, 2013). The overall decline in ice cover is expected to continue (Collins et al., 2013), and the Arctic may become seasonally ice free within a few decades, depending on emissions pathway (Stroeve et al., 2007; Wang and Overland, 2009, 2012; Massonnet et al., 2012; Overland and Wang, 2013; Jahn et al., 2016; Notz and Stroeve, 2016). However, internal variability confounds prediction of this timing (Swart et al., 2015; Jahn et al., 2016; Labe et al., 2018), and even the definition of ice free differs among Arc- 
tic stakeholders (Ridley et al., 2016). Nonetheless, navigation through the Arctic has already increased in frequency as a result of this decline (Melia et al., 2016; Eguíluz et al., 2016), and even more trade routes associated with the increased icefree season are expected throughout the 21st century (Aksenov et al., 2015; Stephenson et al., 2013).

As the Arctic sea ice pack thins and retreats, multiyear ice is being lost and there is consequently a larger proportion of seasonal thin first-year ice (Kwok et al., 2010; Maykut, 1978; Holland et al., 2006). Overall thinner ice may result in an ice pack that exhibits greater interannual variability (Maslanik et al., 2007b; Goosse et al., 2009; Notz, 2009; Kay et al., 2011; Holland and Stroeve, 2011; Döscher and Koenigk, 2013), at least partially due to enhanced ice growth and melt (Maykut, 1978; Holland et al., 2006; Bathiany et al., 2016). Decreased ice thickness promotes amplification of a positive ice-albedo feedback, which can magnify sea ice anomalies (Grenfell and Maykut, 1977; Maykut, 1982; Ebert and Curry, 1993; Perovich et al., 2007; Hunke and Lipscomb, 2010), and thin ice is more vulnerable to anomalous atmospheric forcing and oceanic transport due to the smaller amount of energy required to completely melt the ice (Maslanik et al., 1996; Zhao et al., 2018) and deform the ice dynamically (Hibler, 1979). For example, pulse-like increases in oceanic heat transport can trigger abrupt ice-loss events in sufficiently thin ice (Woodgate et al., 2012).

Changes in the interannual variability in sea ice coverage have been studied only in a limited capacity, likely because they are only beginning to become visible in September in the present day. Both Goosse et al. (2009) and Swart et al. (2015; their Fig. S6 in the Supplement) reported that maximum ice area variability during September occurs once the mean ice extent declines to 3-4 million $\mathrm{km}^{2}$. This increased variability may occur due to increased prevalence of RILEs and periods of rapid recovery during this timeframe (Döscher and Koenigk, 2013). The thickness distribution during these periods skews toward thinner ice, which is conducive to both rapid ice loss and rapid recovery processes (Tietsche et al., 2011; Döscher and Koenigk, 2013). Holland et al. (2008) considered a critical ice thickness that can serve as a precursor to RILEs but found it more likely that intrinsic variability played the primary role in the particular RILEs that were studied. More recently, Massonnet et al. (2018) analyzed the projected variability in sea ice volume and its projected future change in the CMIP5 ensemble, which suggested a monotonic future decrease. The corresponding variability in sea ice area was investigated by Olonscheck and Notz (2017), but their analysis was much coarser temporally and seasonally than our study, in that it only compared changes between two discrete time periods (the historical 1850-2005 period vs. the future 2006-2100 interval) and was further restricted to the summer and winter seasons.

Building on these previous studies, our paper has two novel aspects. First, we analyze the transient interannual variability in sea ice area over the course of the year from the early 20th century through the entire 21 st century and find very different behavior across the four seasons. These monthly differences are societally important because marine access to the Arctic will likely expand beyond late summer as the ice pack shrinks. Second, we detail how interannual sea ice area variability changes as the ice pack retreats, and we link enhanced future variability to optimal ice thicknesses and to the various thermodynamic and dynamic processes that control ice area variability. We analyze a large 40-member ensemble from a single global climate model (GCM), which allows us to isolate internal variability, which is otherwise muddled with inter-model variability in multi-model comparisons. This allows us to test the hypothesis that interannual Arctic sea ice cover variability will increase throughout the year in the future as the ice pack diminishes.

\section{Data and methods}

Ice thickness, concentration, and area were obtained from simulations of the Community Earth System Model Large Ensemble Project (CESM-LE). Ice concentration refers to the percentage of a given grid cell that is covered by ice, while ice area in this study refers specifically to this percent coverage multiplied by the area of the grid cell, yielding a total Arctic ice-covered area. The CESM-LE was designed to enable an assessment of projected change in the climate system while incorporating a wide range of internal climate variability (Kay et al., 2015). It consists of 40 ensemble members simulating the period 1920-2100 under historical and projected (RCP8.5 emissions scenario only) external forcing. The ensemble members are produced by introducing a small, random round-off level difference in the initial air temperature field for each member. This then generates a consequent ensemble spread that is purely due to simulated internal climate variability. A full description of the CESM-LE is given in Kay et al. (2015), and similar ensembles using the weaker RCP4.5 and RCP2.6 scenarios can be found in Sanderson et al. $(2017,2018)$.

Another data set used in the current study is the model simulations from the Coupled Model Intercomparison Project Phase 5 (CMIP5). Although more than 40 models submitted their simulation results to the Program for Climate Model Diagnosis and Intercomparison (PCMDI), only 12 of them simulated the Arctic sea ice extent of both the monthly means (each individual month) and the magnitude of the seasonal cycle (March minus September sea-ice extent) within 20\% error when compared with observations (Wang and Overland, 2012, 2015). Therefore, we used only these 12 models identified by Wang and Overland (2015) in this study: ACCESS1.0, ACCESS1.3, CCSM4, CESM1(CAM5.1), ECEARTH, HadGEM2-AO, HadGEM2-CC, HadGEM2-ES, MIROC-ESM, MIROC-ESM-CHEM, MPI-ESM-LR, and MPI-ESM-MR. Among the 12 models, half of them use the 
same sea ice model as CESM-LE (CICE; Hunke and Lipscomb, 2010) or a variation of it. If a GCM provided multiple ensemble members, we only kept up to five realizations, so that the total ensemble numbers are close to that used in CESM-LE. There is a total of 33 ensemble members from these 12 models in the RCP8.5 emissions scenario. Sea ice area, rather than ice extent, is computed from these 12 CMIP5 models to be consistent with CESM-LE results.

One of our primary analysis data sets is the time series of monthly ice variables. The ensemble mean of all variables is taken after the statistics are calculated for each ensemble member. The 1-year differences in ice area are calculated for each month separately to remove the confounding effect of amplified variability resulting from a downward trend. Finally, a 10-year running standard deviation is applied to the time series of 1-year differences in monthly ice area, centered on a given year. A value of 10 years was chosen to quantify variability over decadal-scale intervals and to provide an adequate number of years for a standard deviation calculation. The timing and magnitude of variability is generally insensitive to the standard deviation window, however, and whether the 1-year difference in ice area or its raw time series is used.

\section{Results}

\subsection{Sea ice area and its variability}

Sea ice area in the CESM-LE is projected to decline in all months in the 21st century, proceeding in three phases: a fairly stable regime of extensive coverage in the 20th century, then a decline, followed by virtually no ice remaining in summer and autumn months (Fig. 1). Sea ice area variability follows an analogous three-phase progression in months spanning midsummer to early winter (Fig. 2). For example, in September this includes a period of modest variability during the 20th century, then a distinct variability peak in the late 2020s and 2030s that coincides with the maximum rate of ice retreat, and finally negligible variability in the late 21 st century as the Arctic reaches near-ice-free conditions (Fig. 2). The first two phases of this progression in variability occur for months in late winter to early summer (January-June), and suppressed variability would likely emerge beyond the end of the century, assuming that ice cover in these months would continue to retreat. The maximum rate of ice retreat (negative values of the derivative) occurs at a different time in the 21st century in each month, occurring presently in September but not until the end of the century in spring.

The same relationship between ice area and its variability is maintained across CMIP5 models, though with more noise resulting from the aggregation of many different models rather than ensemble members from a single model (Fig. 3). This is most notable in the sea ice area (1-year difference) time series (Fig. 3, blue), indicating that there is considerable spread in when and how the downward trend proceeds each month, as found in Massonnet et al. (2012), but good agreement that variability increases in this timeframe.

The analysis of ice area variability in Figs. 2 and 3 follows that of Goosse et al. (2009) and Swart et al. (2015), but we extend their findings for September to all months and confirm that the variability in ice area is maximized as its total basin area decline is well underway in both CESM-LE ensembles and across CMIP5 models. A direct relationship between the rate of sea ice retreat and the magnitude of variability is evident in nearly all months in CESM-LE and CMIP5: the standard deviation is generally highest when ice declines the fastest (Figs. 1, 2 and S1, S2). Furthermore, the magnitude and timing of peak ice area variability in both sets of experiments differ greatly by season. The peak in magnitude in CESM-LE is most pronounced from November to January when the running standard deviation of ice area exceeds $1 \times 10^{6} \mathrm{~km}^{2}$, while the lowest magnitudes occur in April and May, when the downward trend in ice area does not peak prior to 2100 (Fig. 2). Near the end of the 21 st century, the running standard deviation also shows an increase in the CMIP5 ensembles from December to June (Fig. 3), very similar behavior to that displayed by CESM-LE. However, the magnitude of the increase in the running standard deviation in the CMIP5 ensemble mean is smaller than that in CESM-LE. This is not surprising, as the timing of ice retreat varies among models, so averaging them will smooth out the possible signals. The CMIP5 models therefore provide additional evidence that increased variability is associated with decreasing sea ice coverage.

\subsection{Relationship between ice area variability and thickness}

Because increasing future concentrations of thin ice are likely a primary factor in increased ice area variability, we next consider the relationship between ice thickness and ice area variability in CESM-LE. This is performed by correlating the standard deviation of basin-wide ice area (Fig. 2) with the total area of grid cells with mean ice thickness within a given range for an aggregation of all years and ensemble members, binned at $0.05 \mathrm{~m}$ intervals (Fig. 4). The 20th century data are omitted because both variables are largely stationary for this period. There is a large difference in the maximum correlation coefficient across seasons, but in most months it peaks between $r=0.6$ and $r=0.8$. This peak is associated with the thinnest ice of 0.1 to $0.2 \mathrm{~m}$ from October to January, indicating that the greatest year-to-year variability in basin-wide ice area in these months occurs when there is the greatest coverage of thin sea ice between 0.1 and $0.2 \mathrm{~m}$ thickness. There is a broad peak in the correlation coefficient between 0.25 and $0.40 \mathrm{~m}$ in August and September, while July peaks near $0.45 \mathrm{~m}$ thickness but with a weaker maximum correlation coefficient $(r=0.6)$. In June, $r=0.6$ for most ice thicknesses below $0.8 \mathrm{~m}$, and there is only a weak correlation between these variables in April and May. 


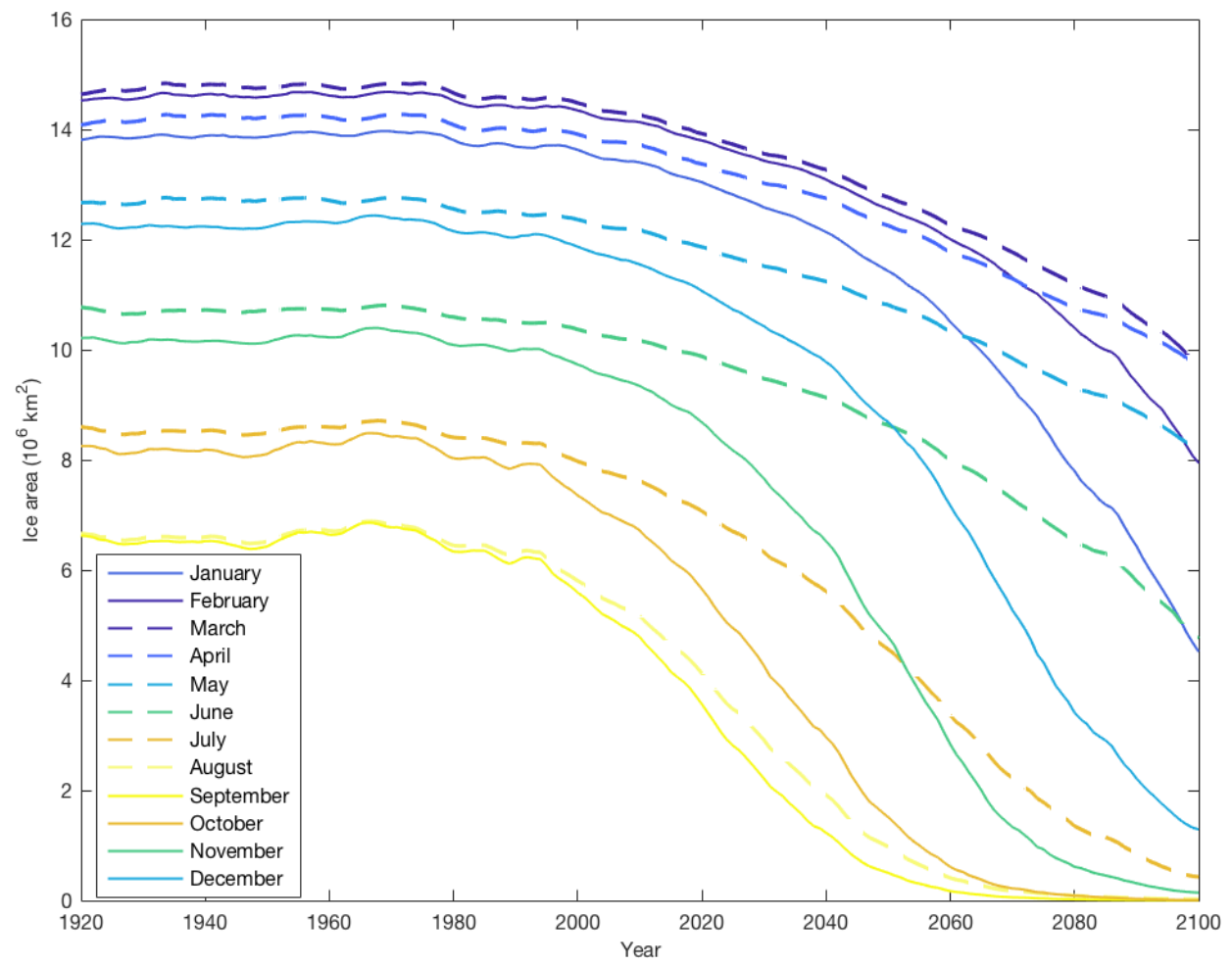

Figure 1. The CESM-LE ensemble mean time series of monthly sea ice area $\left(\mathrm{km}^{2} \times 10^{6}\right)$.
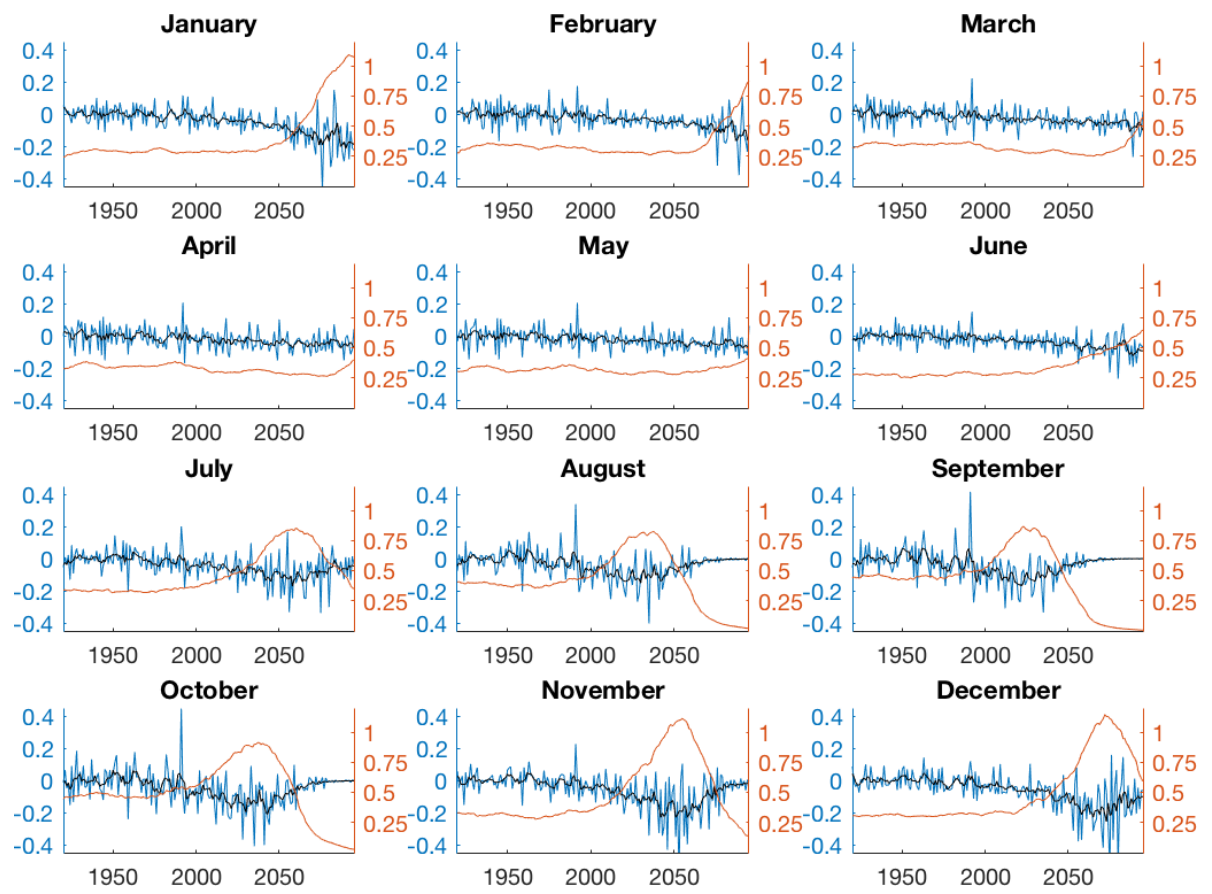

Figure 2. The CESM-LE ensemble mean of the 1-year differences in sea ice area (blue; million $\mathrm{km}^{2}$ ) with their 5-year running mean overlaid (black) and the running standard deviation of the interannual change in sea ice area (gold; million $\mathrm{km}^{2}$ ). 

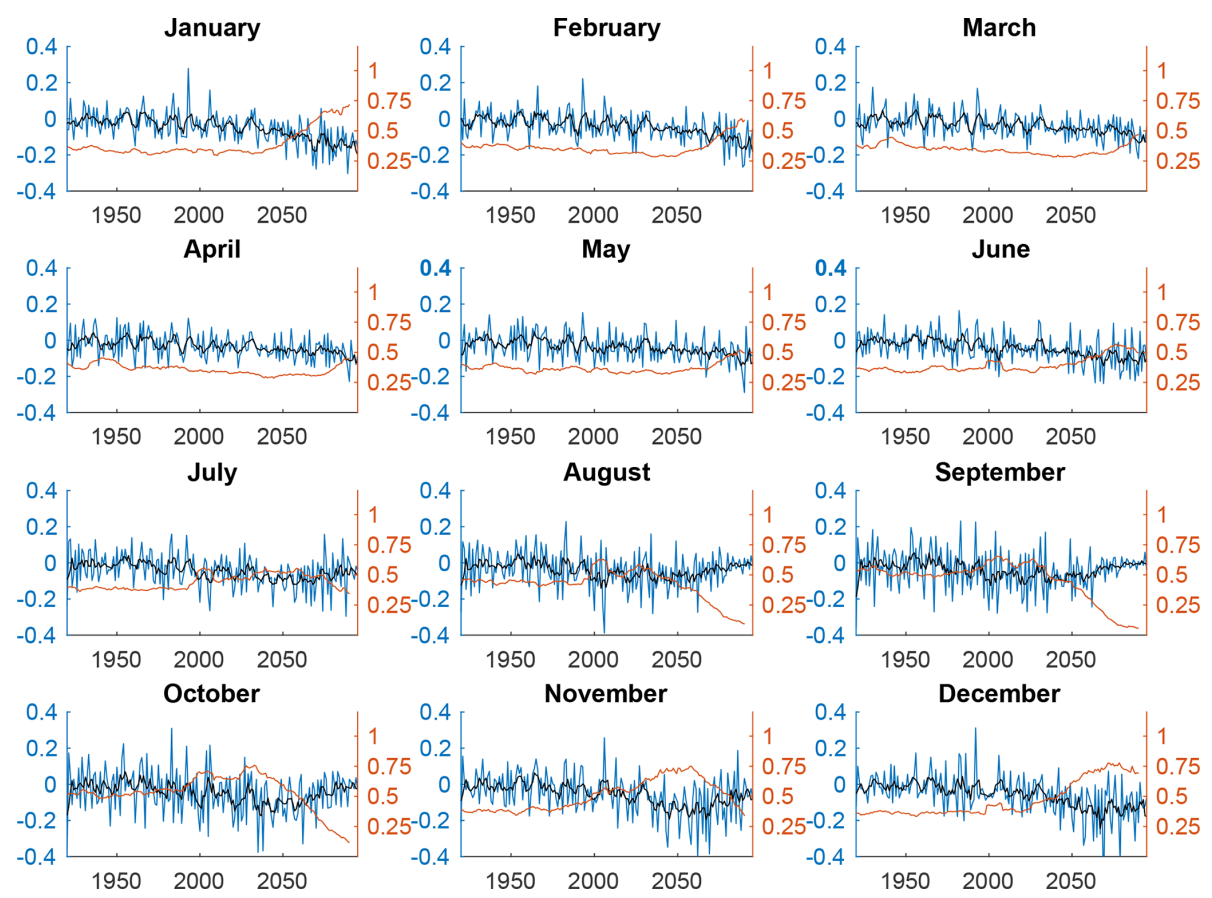

Figure 3. As in Fig. 2, but for the ensemble mean from 12 CMIP5 models' sea ice area.

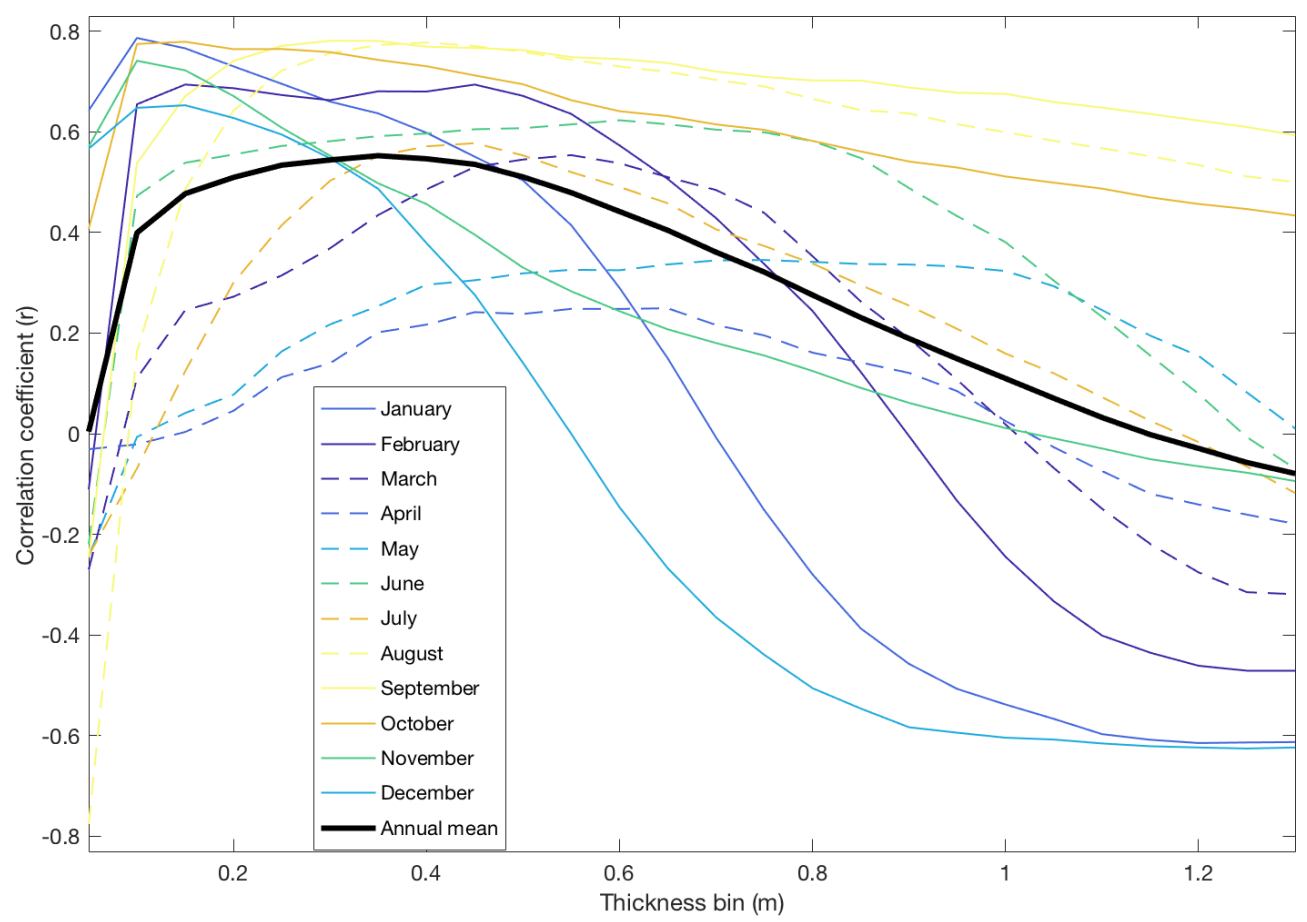

Figure 4. Monthly correlation coefficient $(r)$ of the 2000-2100 10-year running standard deviation of 1-year difference in sea ice area with mean grid cell ice thickness binned every $0.05 \mathrm{~m}$ of thickness.

The analysis in Fig. 4 allows us to identify a common range of ice thicknesses when ice area variability generally peaks regardless of the month, which we approximate as 0.2 to $0.6 \mathrm{~m}$. We next track the temporal evolution of this thin ice throughout the basin by calculating the total area of ice that falls within that range. The time-transgressive nature of when the peak in thin ice cover occurs (earliest in September, latest in winter-spring) is consistent with the corresponding timing 

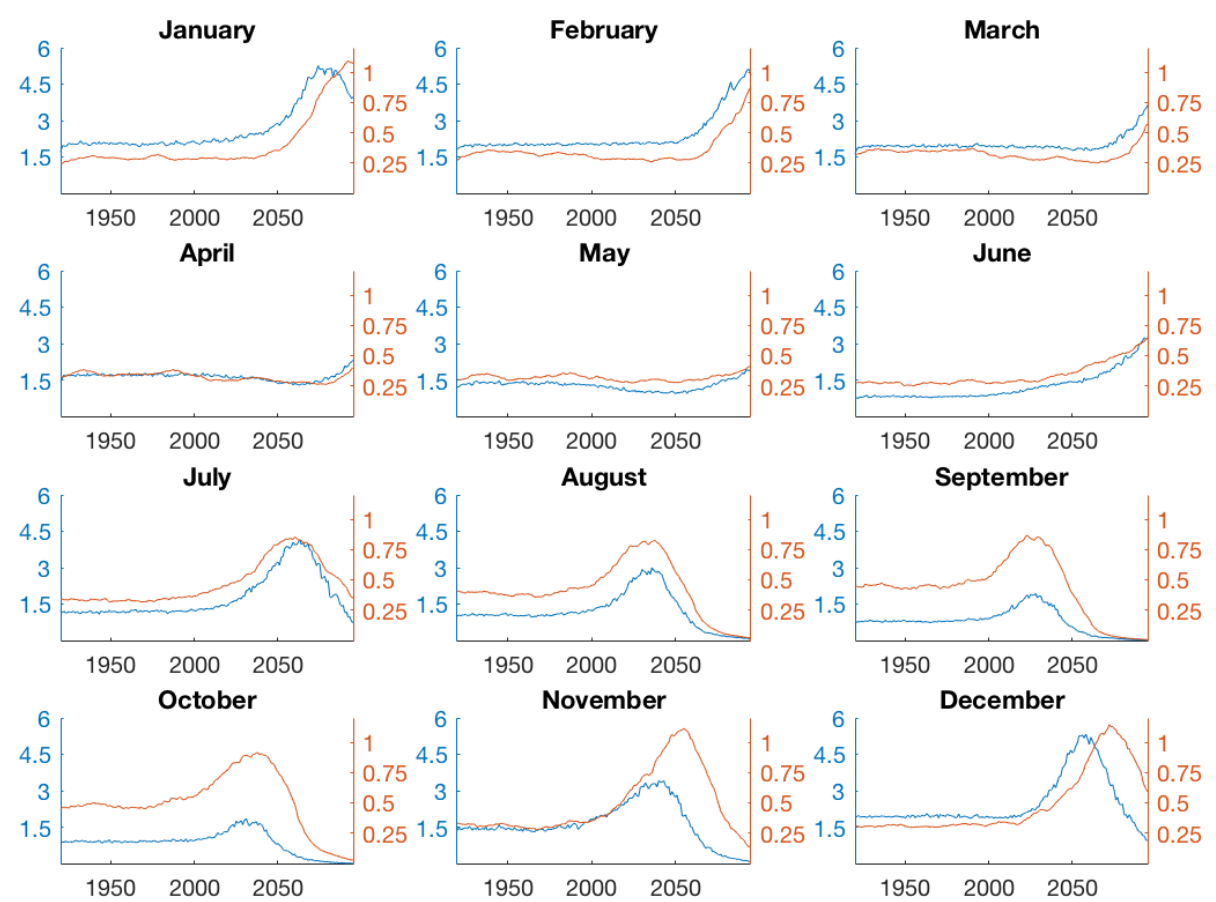

Figure 5. The CESM-LE ensemble mean of the 10-year running standard deviation of 1-year difference in sea ice area from Fig. 1 (gold; million $\mathrm{km}^{2}$ ) and the ensemble mean total area of grid cells with mean ice thickness between 0.2 and $0.6 \mathrm{~m}\left(\mathrm{blue} ; \mathrm{million}^{2} \mathrm{~km}^{2}\right.$ ).

of the peak future sea ice area variability, suggesting that the emergence of a sufficiently thin and contracted ice pack is a primary factor for enhanced ice cover variability (Fig. 5). Both curves match each other in shape, with a steady state early, increasing to a peak and dropping to zero as the Arctic becomes ice free. The exception is in the spring and early summer when neither increases until the end of the 21 st century, when ice begins to decline more rapidly. The two curves are largely in phase as well, with one preceding the other by no more than 10-20 years in July, August, and NovemberJanuary. The phase difference is due to the chosen range of ice thicknesses, since the best relationship varies by month (Fig. 4). The two curves are in phase from August to October (Fig. 5) when the 0.2 to $0.6 \mathrm{~m}$ range approximates the best relationship between thickness and variability (Fig. 4). However, ice area variability maximizes after the peak in $0.2-$ $0.6 \mathrm{~m}$ thickness area in November-January because variability is more highly correlated with ice slightly thinner than $0.2 \mathrm{~m}$ in these months (Figs. 4, 5).

There are also notable seasonal differences in the spatial pattern of variability during the decade when variability in ice concentration peaks in CESM-LE (Fig. 6). The largest fluctuations occur in a horseshoe-shaped pattern across the Arctic Ocean in autumn, but they are restricted to the boundaries of the Atlantic and Pacific oceans in late winter and spring. The result is a larger area of high variability in the second half of the year and into January. The mean $0.2 \mathrm{~m}$ (dotted) and $0.6 \mathrm{~m}$ (solid) ice thickness contours are overlaid for reference (Fig. 6). The contours correspond closely to the boundary of maximum variability in ice coverage in most months, which is consistent with results from Figs. 4 and 5. This demonstrates the first-order relationship between thin ice and the variability in interannual ice coverage within a given region.

\subsection{Ice concentration tendency}

The strong relationship between thin ice coverage and high concentration variability occurs primarily due to the differing underlying mechanisms controlling ice concentration variability at a given time, namely whether ice is expanding or retreating. To illustrate this, we chose two months representative of these processes, September and December, to conduct an in-depth analysis of the physical mechanisms involved in the time difference in the two curves in Fig. 5. September is the end of the melt season, and therefore the ice concentration over the entire basin in this month reflects the cumulative impact of melt processes throughout the summer. By contrast, December is a time of ice growth, particularly in the future, and thus the ice concentration in this month is largely regulated by cumulative growth processes during autumn. Using available model output, we calculate the ice concentration tendency $\left(\% \mathrm{day}^{-1}\right)$ from thermodynamics and dynamics in the regions where the decadal standard deviation of ice concentration exceeds $30 \%$ within the grid cell (Fig. S3) to evaluate the mean ice budget. These regions of maximum variability in September and December closely match those in Fig. 6, though the magnitude is smaller in Fig. 6 due to the 


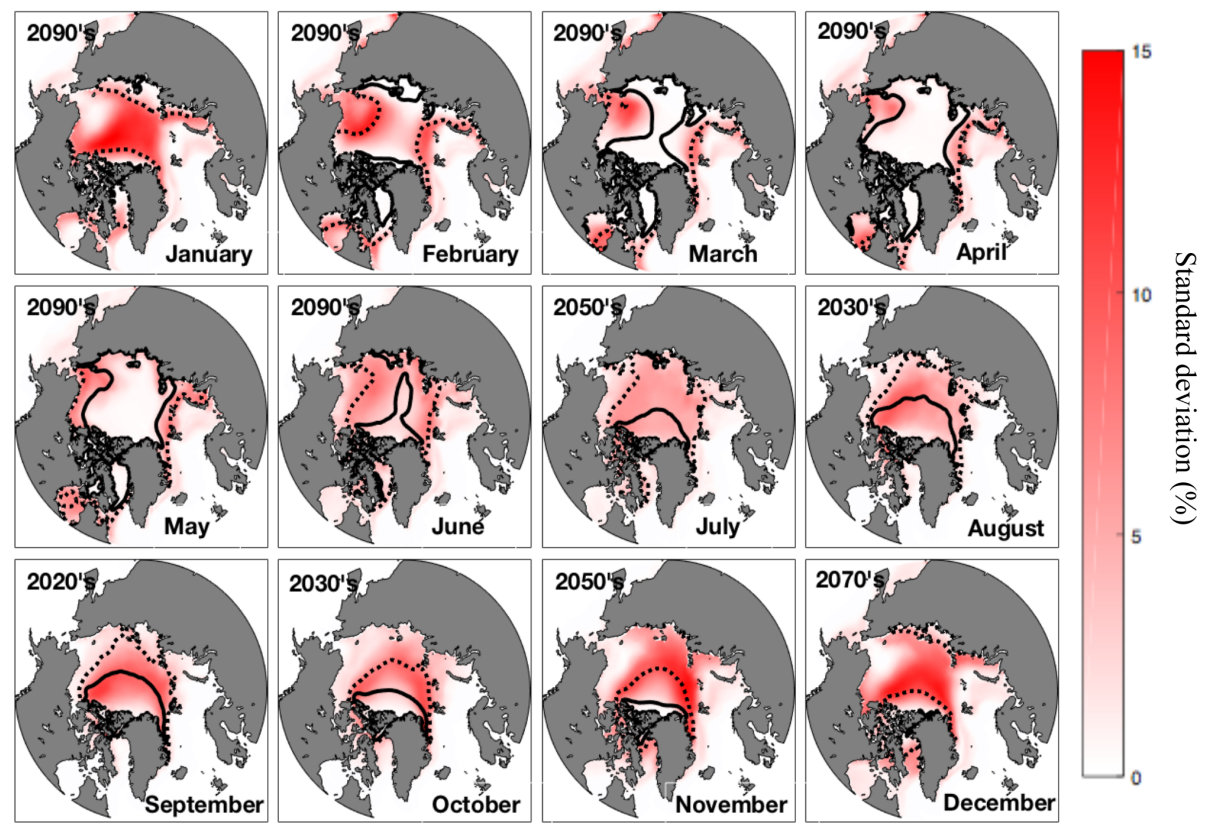

Figure 6. Monthly ensemble average in CESM-LE of the 10-year running standard deviation of ice concentration (\%) in the decade when ice area variability is at a maximum. Mean 0.2 and $0.6 \mathrm{~m}$ ice thicknesses are indicated by the dotted and solid contours, respectively.

standard deviation being a decadal mean. The daily change in ice concentration is a function of dynamic contributions (ice import-export and ridging), thermodynamic melt processes (the sum of top, bottom, and lateral), and thermodynamic growth (frazil and congelation). Because antecedent conditions of the ice pack can be an important factor for determining ice concentration in the month of interest, we sum these terms over the preceding months (July-September or October-December) and report the net 3-month change in ice concentration resulting from each component.

The most interannually variable ice cover during September occurs primarily in the 2020s and is centered across the central Arctic (Fig. S3), though this region displays net ice expansion in July-September in the 20th century (Fig. 7a) due to rapid ice growth in September. Thermodynamic processes dominate over dynamics and are of opposing sign during the 20th century, and thermodynamic processes add an average of $20 \%$ to the ice concentration of each grid cell in the region by the end of September, compared with a loss of only $10 \%$ from dynamical processes (Fig. 7a). Ice growth diminishes and melt processes accelerate in the early to mid21 st century when the melt processes reduce ice concentration by more than $75 \%$ and the dynamic processes essentially disappear with less ice to export (Fig. 7a). After 2060, September ice-free conditions occur, and the thermodynamic term becomes less negative due to reduced areal coverage of ice in June and hence less ice area to melt over the summer (Fig. 7a).

Because thermodynamic processes dominate in controlling ice concentration in the future, they should also be the first-order forcing explaining future ice concentration variability, particularly given that the magnitude of the dynamic contribution approaches zero by the 2020 s when ice cover is rapidly diminishing. As shown in Fig. 7b, the peak interannual variability in the thermodynamic term (red curve) is indeed several times larger than peak variability in the dynamic term (blue curve), and the variability in the thermodynamic term maximizes during the late 2020s in phase with the variability in the ice concentration (green curve) when the thermodynamic term is declining most rapidly in Fig. 7a. The variability likely also reflects the influence of the surface albedo feedback in amplifying summer ice area variations. There is a secondary rise in the variability in the thermodynamic term after 2060 (Fig. 7b), coinciding with its rapid rise toward zero in Fig. 7a, but ice coverage by this point is confined to a diminishing area.

From the 20th century well into the 21 st century, ice growth occurs in the October-December period in a similar region of maximum interannual variability as September, except slightly equatorward (Fig. S3). Ice export plays a relatively larger role in the regions of interest in December than in September (Fig. 7c). However, the thermodynamic tendency is still the dominant term controlling ice concentration within this region of maximum interannual variability, and this term increases in the early to mid-21st century to a total of nearly $120 \%$, some of which is offset by ice export that contributes to a $40 \%$ decrease in mean ice concentration in the 20th and early 21 st centuries (Fig. 7c). The increased net ice growth occurs at this time primarily because there is more initial open water on which frazil ice can form. 
(a) September ice concentration and tendency
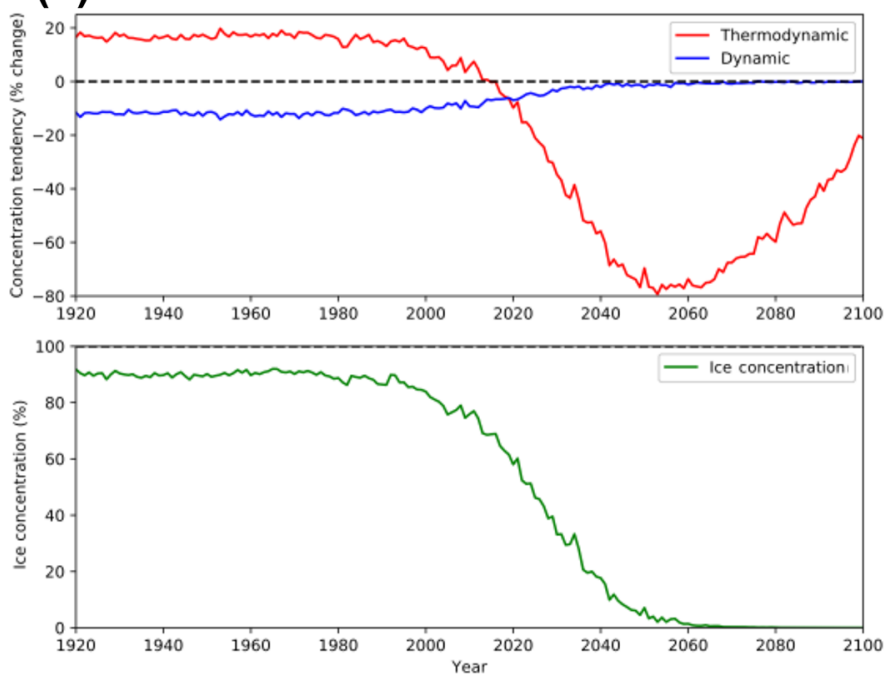

(c) December ice concentration and tendency
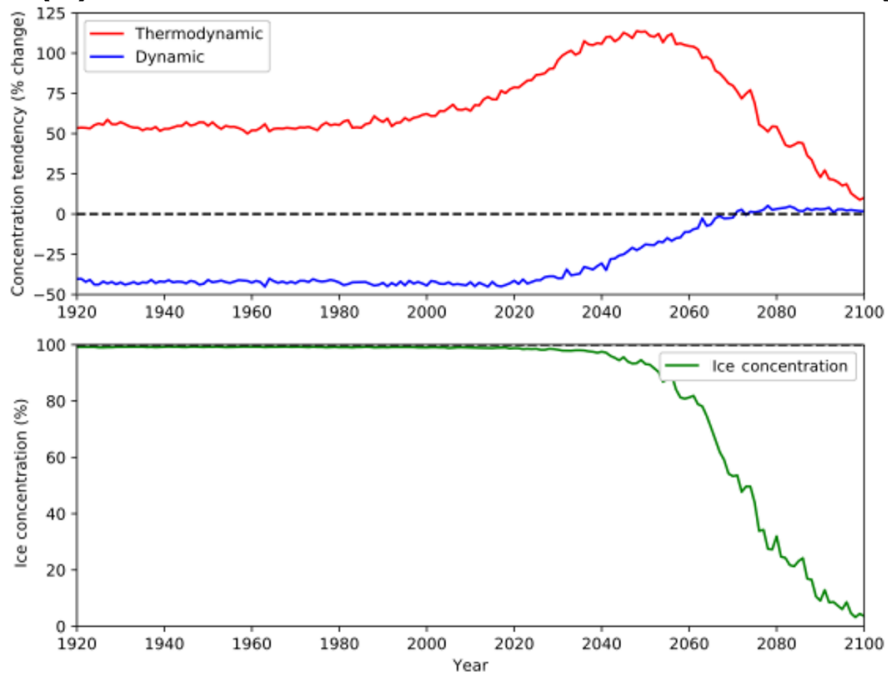

(b) Variability in ice concentration and tendency

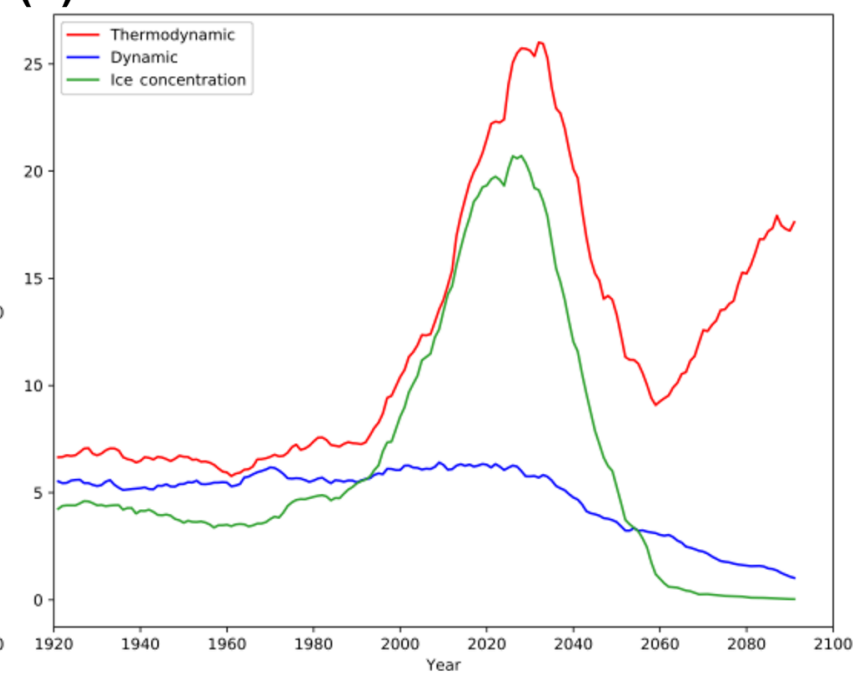

(d) Variability in ice concentration and tendency

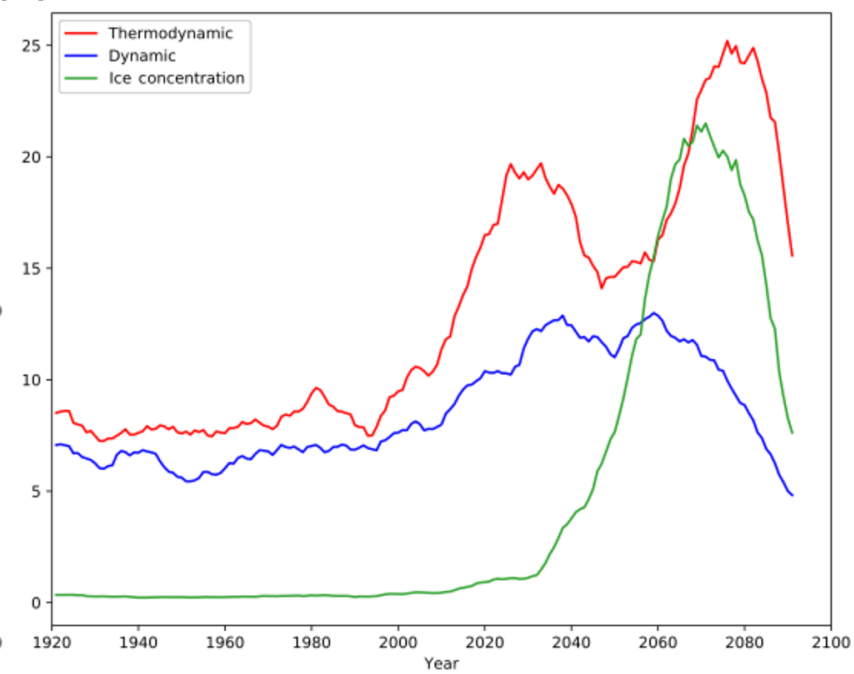

Figure 7. Time series of ensemble-mean (a) September ice concentration (\%) and July-September averaged concentration tendency $\left(\%\right.$ day $\left.^{-1}\right)$ from dynamics and thermodynamics, and (b) the 10-year running standard deviation of the interannual difference in ice concentration $(\%)$, and July-September ice concentration tendency from dynamics and thermodynamics $\left(\%\right.$ day $\left.^{-1}\right)$. The same information is presented in panels (c) and (d) for December concentration and October-December ice concentration tendency terms.

Figure $7 \mathrm{~d}$ shows that the standard deviation of December ice concentration (green curve) peaks around 2070 and is accompanied by a peak in the variability in the thermodynamic tendency (red curve) of more than double the magnitude of its dynamic tendency (blue curve). A smaller first peak in thermodynamic tendency occurs in the 2020s, when ice growth in this region increases due to increased frazil growth as this region's waters become more open on average in October. This initial peak may be smaller due to the anticorrelation between dynamic and thermodynamic tendency, which reduces the effect of the latter. The rapid subsequent decline in ice growth occurs as conditions become too warm for ice growth over much of the October-December period in the 2050s and 2060s (Fig. 7c). This is reflected in the peak in variability in the thermodynamic tendency (red curve) approximately corresponding to the timing of the peak in the ice area variability (green curve) in 2070 (Fig. 7d). The coincidence in their peak variability is similar to that in Fig. $7 \mathrm{~b}$ and underscores the dominance of thermodynamics over dynamics in regulating the variability in ice area.

\section{Discussion and conclusions}

This study has assessed the behavior of interannual Arctic sea ice area variability in the past and future, using a large set of independent realizations from CESM-LE and simulations 
from 12 models participating in CMIP5. The results demonstrate the complex, time-varying response of the ice pack as it transitions from a relatively stable state during the 20th century to a more volatile state. A few of our most important findings are summarized below.

1. Interannual variability in Arctic sea ice cover increases (at least transiently) in all months in the future as sea ice area and thickness decline, but there is a strong seasonal dependence. There is also a strong seasonal dependence of the magnitude of the maximum ice area variability in the future, with the greatest magnitude occurring during autumn and winter and smallest during spring by the time the simulation ends in 2100 (Figs. 2-3). The future peak in variability emerges soonest in late-summer months and latest during spring months, and the magnitude of this peak is positively correlated with the rate of ice loss in every month.

It is possible that the seasonal differences in ice area variability are partially a construction of the geography of the Arctic Basin, as evident in Fig. 6: when the ice margin is geographically constrained and unable to expand and contract due to a coastline early in the simulation, there is a smaller area subject to high ice variability. This explanation was offered by Goosse et al. (2009) for the same relationship in summer ice area variability, as well as by Eisenman (2010), to explain retreat rate differences between summer and winter. In the future, the ice in the central Arctic Ocean becomes thin enough to expand and contract extensively each season, leading to an increase in variability. Therefore, variability could be considered to be limited particularly in the first phase of its time series (Fig. 2) by the inability of ice to spread across a large open area. Support for this interpretation comes from our calculation of Eisenman's equivalent ice area applied to Fig. 1 (not shown), which resulted in the largest absolute decline in sea ice during the winter-spring months, though summer-autumn ice loss was still greater in relative terms. While useful for approximating potential sea ice extent in the absence of geographic constraints, equivalent ice area is still a theoretical construct; our purpose is to assess the variability in ice cover that actually exists. Furthermore, results from Figs. 4 and 5 suggest that the amount of thin ice alone can explain the evolution of ice variability in every month, though differences in the optimal ice thickness by month may require a partial geographical explanation, in addition to one incorporating the components of the thermodynamic tendency of ice area from Fig. 7.

2. Ice needs to be sufficiently thin before areal variability maximizes, and in CESM-LE the optimal thickness range is generally between 0.2 and $0.6 \mathrm{~m}$ but with some seasonal dependence resulting from the ice melt or ice growth processes that dominate in a given sea- son (Figs. 4-5). The mean ice thickness in late summer and autumn is close to $0.6 \mathrm{~m}$ when ice area variability is highest, but is $0.2 \mathrm{~m}$ or less for a grid cell average in the winter.

Increased ice area variability in summer and autumn is partly attributable to a higher efficiency of open water formation with the thinning sea ice (Holland et al., 2006; Massonnet et al., 2018) and the fact that smaller heating anomalies are required to completely melt through vast areas of the thin ice pack (Bitz and Roe, 2004). We find that the total area of thin ice between the range of 0.2 and $0.6 \mathrm{~m}$ is closely related to how soon and how strongly the peak variability in basinwide ice area emerges, and this is primarily a function of variability in ice area's thermodynamic tendency. This result is consistent with a physical understanding of this relationship since ice that is too thin tends to be seasonal and melt off every year, whereas thick ice is more likely to survive the melt season. Seasonal forecasting of September sea ice coverage takes advantage of this concept, with the forecast skill improved when initializing ice thickness up to 8 months in advance (Chevallier and Salas-Melia, 2012; Day et al., 2014).

In contrast, ice area variability in November-January arises primarily from interannual variability in ice growth (as represented by December in Fig. 7c, d), which is dependent on existing open water conditions and temperature anomalies. The peak in ice area variability in these months also coincides with a slightly lower mean ice thickness of $0.2 \mathrm{~m}$, though it is unclear whether that is due to this ice growth processes rather than melt processes at work during the winter.

3. Interannual variability in ice concentration is driven primarily by thermodynamic mechanisms, which are primarily comprised of either ice growth or ice melt depending on the season. Despite being opposing processes, their magnitudes exceed those of dynamic ice processes (Fig. 7).

The thermodynamic tendency in ice concentration is of much greater magnitude than its dynamic counterpart at both the end of the melt season and start of the growth season, and the maximum interannual variability in the thermodynamic term is mostly in phase with that of ice concentration. The inverse relationship between ice area's interannual variability and its interannual rate of change (Figs. 1, 2, S1, S2) is also found between the thermodynamic tendency and its rate of change (not shown, but inferred from Fig. 7). This is further evidence that ice area variability is primarily driven by thermodynamic processes in the ice pack.

The dominance of the thermodynamic tendency is unsurprising and has been established as the relatively more important set of processes controlling sea ice vari- 
ability, primarily via transport of midlatitude eddy heat flux anomalies (Kelleher and Screen, 2018), anticyclone passage (Wernli and Papritz, 2018), and increased ocean heat transport ( $\mathrm{Li}$ et al., 2018). However, the dynamic contribution to changes in ice concentration can likely be substantial in the absence of regional and monthly averaging, and numerous mechanisms have been described that can generate increased ice transport. Recent examples include divergent ice drift events connected to anomalous circulation patterns (Zhao et al., 2018) as well as the collapse of the Beaufort high (Petty, 2018; Moore et al., 2018), both of which may become more common in the future due to preconditioning of the ice pack and further intrusion of midlatitude cyclones into the Arctic.

This study offers a unique contribution by focusing on the projected transient evolution of Arctic sea ice area variability throughout the year, as characterized by its response to external greenhouse forcing superimposed on short-term internal variability. A recent study (Olonscheck and Notz, 2017) also identified an overall increase in projected interannual variability in summertime sea ice area in CMIP5, but this conclusion was not consistent across all models, possibly because the analysis did not incorporate the pronounced changes in variability over time as the ice pack diminishes. Interestingly, another recent study (Massonnet et al., 2018) revealed that CESM-LE simulates a future decrease in interannual variability in sea ice volume, due to the dominance of the sea ice thickness term. Contrary to the behavior of ice area variability analyzed here, their analysis showed that interannual variability in ice thickness consistently declines when the ice pack thins. This relationship is a robust thermodynamic consequence of a strengthened "ice-formation efficiency", indicative of an enhanced stabilizing ice thickness-ice growth feedback (Notz and Bitz, 2017) caused by greater wintertime vertical ice growth following summers with pronounced ice thinning. Therefore, it is important to distinguish which term (area or thickness) is being considered when assessing future changes in the variability in the ice pack.

Increased interannual variability in sea ice area in the CESM Large Ensemble as sea ice declines most rapidly is an important result that needs to be accounted for as the icefree season expands and the timing of maximum variability shifts from September. We also confirm that this relationship is maintained across CMIP5 models, suggesting that the responsible mechanisms reported here may apply more generally. These results have important implications for marine navigation going forward, indicating that the otherwise auspicious transition to diminished sea ice in every month may be accompanied by a confounding increase in interannual variability in the ice cover before the ice disappears completely.
Data availability. CESM LE data are publicly available at the National Center for Atmospheric Research Climate Data Gateway (https://www.earthsystemgrid.org/, last access: 12 May 2018). CMIP5 data are publicly available and hosted by Lawrence Livermore National Laboratory (https://esgf-node.llnl.gov/projects/ cmip5/, last access: 15 November 2017).

Supplement. The supplement related to this article is available online at: https://doi.org/10.5194/tc-13-113-2019-supplement.

Author contributions. JRM analyzed the CESM data and prepared the paper, MW provided CMIP5 data and guidance, SV assisted in paper preparation and revision, and $\mathrm{MH}$ and LL provided guidance and edits.

Competing interests. The authors declare that they have no conflict of interest.

Acknowledgements. We thank the two anonymous reviewers for their helpful comments. Support was provided by the NOAA Climate Program Office under Climate Variability and Predictability Program grant NA15OAR4310166. This project is partially funded by the Joint Institute for the Study of the Atmosphere and Ocean (JISAO) under NOAA Cooperative Agreement NA10OAR4320148, contribution number 2017-087, the Pacific Marine Environmental Laboratory contribution number 4671. We would like to acknowledge high-performance computing support from Yellowstone (ark:/85065/d7wd3xhc) provided by NCAR's Computational and Information Systems Laboratory, sponsored by the National Science Foundation.

Edited by: Dirk Notz

Reviewed by: Dirk Olonscheck and one anonymous referee

\section{References}

Aksenov, Y., Popova, E. E., Yool, A., Nurser, J. G., Williams, T. D., Bertino, L., and Bergh, J.: On the future navigability of Arctic sea routes: High-resolution projections of the Arctic Ocean and sea ice, Mar. Policy, 75, 1-18, https://doi.org/10.1016/j.marpol.2015.12.027, 2015.

Bathiany, S., van der Bolt, B., Williamson, M. S., Lenton, T. M., Scheffer, M., van Nes, E. H., and Notz, D.: Statistical indicators of Arctic sea-ice stability - prospects and limitations, The Cryosphere, 10, 1631-1645, https://doi.org/10.5194/tc-10-16312016, 2016.

Bitz, C. M. and Roe, G. H.: A mechanism for the high rate of sea ice thinning in the Arctic Ocean, J. Climate, 17, 3623-3632, https://doi.org/10.1175/15200442(2004)017<3623:AMFTHR>2.0.CO;2, 2004.

Cavalieri, D. J. and Parkinson, C. L.: Arctic sea ice variability and trends, 1979-2010, The Cryosphere, 6, 881-889, https://doi.org/10.5194/tc-6-881-2012, 2012. 
Chevallier, M. and Salas-Melia, D.: The Role of Sea Ice Thickness Distribution in the Arctic Sea Ice Potential Predictability: A Diagnostic Approach with a Coupled GCM, J. Climate, 25, 30253038, 2012.

Collins, M., Knutti, R., Arblaster, J., Dufresne, J.-L., Fichefet, T., Friedlingstein, P., Gao, X., Gutowski, Jr, W. J., Johns, T., Krinner, G., Shongwe, M., Tebaldi, C., Weaver, A. J., and Wehner, M.: Long-term Climate Change: Projections, Commitments and Irreversibility, in: Climate Change 2013: The Physical Science Basis, Contribution of Working Group I to the Fifth Assessment Report of the Intergovernmental Panel on Climate Change, edited by: Stocker, T. F., Qin, D., Plattner, G.-K., Tignor, M., Allen, S. K., Boschung, J., Nauels, A., Xia, Y., Bex, V., and Midgley, P., Cambridge University Press, Cambridge, UK and New York, NY, USA, 12, 1029-1136, 2013.

Comiso, J. C., Meier, W. N., and Gersten, R.: Variability and trends in the Arctic Sea ice cover: Results from different techniques, J. Geophys. Res.-Oceans, 122, 1-22, https://doi.org/10.1002/2017JC012768, 2017.

Day, J. J., Tietsche, S., and Hawkins, E.: Pan-Arctic and regional sea ice predictability: Initialization month dependence, J. Climate, 27, 4371-4390, 2014.

Ding, Q., Schweiger, A., L'Heureux, M., Battisti, D. S., Po-Chedley, S., Johnson, N. C., Blanchard-Wrigglesworth, E., Harnos, K., Zhang, Q., and Eastman, R.: Influence of high-latitude atmospheric circulation changes on summertime Arctic sea ice, Nat. Clim. Change, 7, 289-295, https://doi.org/10.1038/nclimate3241, 2017.

Döscher, R. and Koenigk, T.: Arctic rapid sea ice loss events in regional coupled climate scenario experiments, Ocean Sci., 9, 217248, https://doi.org/10.5194/os-9-217-2013, 2013.

Ebert, E. E. and Curry, J. A.: An intermediate one-dimensional thermodynamic sea ice model for investigating iceatmosphere interactions, J. Geophys. Res., 98, 10085-10109, https://doi.org/10.1029/93JC00656, 1993.

Eguíluz, V. M., Fernández-Gracia, J., Irigoien, X., and Duarte, C. M.: A quantitative assessment of Arctic shipping in 2010-2014, Sci. Rep., 6, 30682, https://doi.org/10.1038/srep30682, 2016.

Eisenman, I.: Geographic muting of changes in the Arctic sea ice cover, Geophys. Res. Lett., 371, L16501, https://doi.org/10.1029/2010GL043741, 2010.

Goosse, H., Arzel., O., Bitz, C. M., de Montety, A., and Vancoppenolle, M.: Increased variability of the Arctic summer ice extent in a warmer climate, Geophys. Res. Lett., 36, L23702, https://doi.org/10.1029/2009GL040546, 2009.

Grenfell, T. C. and Maykut, G. A.: The optical properties of ice and snow in the Arctic Basin, J. Glaciol., 18, 445-463, https://doi.org/10.3189/S0022143000021122, 1977.

Hibler, W. D.: A dynamic thermodynamic sea ice model, J. Phys. Oceanogr., 9, 815-846, 1979.

Holland, M. M. and Stroeve, J.: Changing seasonal sea ice predictor relationships in a changing Arctic climate, Geophys. Res. Lett., 38, L18501, https://doi.org/10.1029/2011GL049303, 2011.

Holland, M. M., Bitz, C. M., and Tremblay, B.: Future abrupt reductions in the summer Arctic sea ice, Geophys. Res. Lett., 33, 1-5, https://doi.org/10.1029/2006GL028024, 2006.

Holland, M. M., Bitz, C. M., Tremblay, B., and Bailey, D. A.: The role of natural versus forced change in future rapid summer Arctic ice loss. Arctic sea ice decline: Observations, pro- jections, mechanisms, and implications, edited by: DeWeaver, E. T., Bitz, C. M., and Tremblay, L. M., Geophysical Monograph Series, American Geophysical Union, Washington, 133150, https://doi.org/10.1029/180GM10, 2008.

Hunke, E. C. and Lipscomb, W. H.: CICE: the Los Alamos Sea Ice Model Documentation and Software User's Manual Version 4.1 LA-CC-06-012, T-3 Fluid Dynamics Group, Los Alamos National Laboratory, Los Alamos, NM, USA, 2010.

Jahn, A., Kay, J. E., Holland, M. M., and Hall, D. M.: How predictable is the timing of a summer ice-free Arctic?, Geophys. Res. Lett., 43, 1-8, https://doi.org/10.1002/2016GL070067, 2016.

Kay, J. E., Holland, M. M., and Jahn, A.: Inter-annual to multi-decadal Arctic sea ice extent trends in a warming world, Geophys. Res. Lett., 38, L15708, https://doi.org/10.1029/2011GL048008, 2011.

Kay, J. E., Deser, C., Phillips, A., Mai, A., Hannay, C., Strand, G., Arblaster, J. M., Bates, S. C., Danabasoglu, G., Edwards, J., Holland, M., Kushner, P., Lamarque, J.-F., Lawrence, D., Lindsay, K., Middleton, A., Munoz, E., Neale, R., Oleson, K., Polvani, L., and Vertenstein, M.: The Community Earth System Model (CESM) Large Ensemble Project: A Community Resource for Studying Climate Change in the Presence of Internal Climate Variability, B. Am. Meteorol. Soc., 96, 1333-1349, https://doi.org/10.1175/BAMS-D-13-00255.1, 2015.

Kelleher, M. and Screen, J.: Atmospheric precursors of and response to anomalous Arctic sea ice in CMIP5 models, Adv. Atmos. Sci., 35, 27-37, https://doi.org/10.1007/s00376-017-70399, 2018.

Kwok, R. and Rothrock, D. A.: Decline in Arctic sea ice thickness from submarine and ICESat records: 1958-2008, Geophys. Res. Lett., 36, L15501, https://doi.org/10.1029/2009GL039035, 2009.

Kwok, R., Cunningham, G. F., Wensnahan, M., Rigor, I., Zwally, H. J., and Yi, D.: Thinning and volume loss of the Arctic Ocean sea ice cover: 2003-2008, J. Geophys. Res.-Oceans, 114, 2003 2008, https://doi.org/10.1029/2009JC005312, 2009.

Kwok, R., Pederse, L. T., Gudmandsen, P., and Pang, S. S.: Large sea ice outflow into the Nares strait in 2007, Geophys. Res. Lett, 37, L03502, https://doi.org/10.1029/2009GL041872, 2010.

Labe, Z., Magnusdottir, G., and Stern, H.: Variability of Arctic Sea Ice Thickness Using PIOMAS and the CESM Large Ensemble, J. Climate, 31, 3233-3247, https://doi.org/10.1175/JCLI-D-170436.1, 2018.

Lang, A., Yang, S., and Kaas, E.: Sea ice thickness and recent Arctic warming, Geophys. Res. Lett., 44, 409-418, https://doi.org/10.1002/2016GL071274, 2017.

Li, D., Zhang, R., and Knutson, T.: Comparison of Mechanisms for Low-Frequency Variability of Summer Arctic Sea Ice in Three Coupled Models, J. Climate, 31, 1205-1226, https://doi.org/10.1175/JCLI-D-16-0617.1, 2018.

Maslanik, J. A., Serreze, M. C., and Barry, R. G.: Recent decreases in Arctic summer ice cover and linkages to atmospheric circulation anomalies, Geophys. Res. Lett., 23, 16771680, https://doi.org/10.1029/96GL01426, 1996.

Maslanik, J. A., Drobot, S., Fowler, C., Emery, R., and Barry, R.: On the Arctic climate paradox and the continuing role of atmospheric circulation in affecting sea ice conditions, Geophys. Res. Lett., 34, 2-5, https://doi.org/10.1029/2006GL028269, 2007a. 
Maslanik, J. A., Fowler, C., Strove, J., Drobot, S., Zwally, J., Yi, D., and Emery, W.: A younger, thinner Arctic ice cover: Increased potential for rapid, extensive sea-ice loss, Geophys. Res. Lett., 34, 2004-2008, https://doi.org/10.1029/2007GL032043, 2007 b.

Maslanik, J. A., Stroeve, J., Fowler, C., and Emery, W.: Distribution and trends in Arctic sea ice age through spring 2011, Geophys. Res. Lett., 38, 2-7, https://doi.org/10.1029/2011GL047735, 2011.

Massonnet, F., Fichefet, T., Goosse, H., Bitz, C. M., PhilipponBerthier, G., Holland, M. M., and Barriat, P.-Y.: Constraining projections of summer Arctic sea ice, The Cryosphere, 6, 13831394, https://doi.org/10.5194/tc-6-1383-2012, 2012.

Massonnet, F., Vancoppenolle, M., Goosse, H., Docquier, D., Fifechet, T., and Blanchard-Wrigglesworth, E.: Arctic sea-ice change tied to its mean state through thermodynamic processes, Nat. Clim. Change, 8, 599-603, 2018.

Maykut, G. A.: Energy exchange over young sea ice in the central Arctic, J. Geophys. Res., 83, 3646-3658, https://doi.org/10.1029/JC083iC07p03646, 1978.

Maykut, G. A.: Large-scale heat exchange and ice production in the central Arctic, J. Geophys. Res., 87, 7971-7984, https://doi.org/10.1029/JC087iC10p07971, 1982.

Melia, N., Haines, K., and Hawkins, E.: Sea ice decline and 21st century trans-Arctic shipping routes, Geophys. Res. Lett., 43, 9720-9728, https://doi.org/10.1002/2016GL069315, 2016.

Moore, G. W. K., Schweiger, A., Zhang, J., and Steele, M.: Collapse of the 2017 winter Beaufort High: A response to thinning sea ice?, Geophys. Res. Lett., 45, 2860-2869, https://doi.org/10.1002/2017GL076446, 2018.

Nghiem, S. V., Rigor, I. G., Perovich, D. K., Clemente-Colón, P., Weatherly, J. W., and Neumann, G.: Rapid reduction of Arctic perennial sea ice, Geophys. Res. Lett., 34, 1-6, https://doi.org/10.1029/2007GL031138, 2007.

Notz, D.: The future of ice sheets and sea ice: between reversible retreat and unstoppable loss, P. Natl. Acad. Sci. USA, 106, 20590 20595, https://doi.org/10.1073/pnas.0902356106, 2009.

Notz, D. and Bitz, C. M.: Sea ice in Earth system models, edited by: Thomas, D. N., John Wiley \& Sons, Chichester, UK, 2017.

Notz, D. and Marotzke, J.: Observations reveal external driver for Arctic sea-ice retreat, Geophys. Res. Lett., 39, 1-6, https://doi.org/10.1029/2012GL051094, 2012.

Notz, D. and Stroeve, J.: Observed Arctic sea-ice loss directly follows anthropogenic $\mathrm{CO}_{2}$ emission, Science, 354, 747-750, https://doi.org/10.1126/science.aag2345, 2016.

Olonscheck, D. and Notz, D.: Consistently estimating internal variability from climate model simulations, J. Climate, 30, 95559573, 2017.

Overland, J. E. and Wang, M.: When will the summer Arctic be nearly sea ice free?, Geophys. Res. Lett., 40, 2097-2101, https://doi.org/10.1002/grl.50316, 2013.

Perovich, D. K., Light, B., Eicken, H., Jones, K. F., Runciman, K., and Nghiem, S. V.: Increasing solar heating of the Arctic Ocean and adjacent seas, 1979-2005: Attribution and role in the ice-albedo feedback, Geophys. Res. Lett., 34, 1-5, https://doi.org/10.1029/2007GL031480, 2007.

Petty, A. A.: A possible link between winter Arctic sea ice decline and a collapse of the Beaufort High?, Geophys. Res. Lett., 45, 2879-2882, https://doi.org/10.1002/2018GL077704, 2018.
Ridley, J. K., Wood, R. A., Keen, A. B., Blockley, E., and Lowe, J. A.: Brief Communication: Does it matter exactly when the Arctic will become ice-free?, The Cryosphere Discuss., https://doi.org/10.5194/tc-2016-28, in review, 2016.

Sanderson, B. M., Xu, Y., Tebaldi, C., Wehner, M., O'Neill, B., Jahn, A., Pendergrass, A. G., Lehner, F., Strand, W. G., Lin, L., Knutti, R., and Lamarque, J. F.: Community climate simulations to assess avoided impacts in 1.5 and $2{ }^{\circ} \mathrm{C}$ futures, Earth Syst. Dynam., 8, 827-847, https://doi.org/10.5194/esd-8-827-2017, 2017.

Sanderson, B. M., Oleson, K. W., Strand, W. G., Lehner, F., and O'Neill, B. C.: A new ensemble of GCM simulations to assess avoided impacts in a climate mitigation scenario, Climatic Change, 146, 303-318, 2018.

Serreze, M. C. and Stroeve, J. C.: Arctic sea ice trends, variability and implications for seasonal ice forecasting, Philos. T. Roy. Soc. A, 373, 20140159, https://doi.org/10.1098/rsta.2014.0159, 2015.

Stammerjohn, S., Massom, R., Rind, D., and Martinson, D.: Regions of rapid sea ice change: An inter-hemispheric seasonal comparison, Geophys. Res. Lett., 39, L06501, https://doi.org/10.1029/2012GL050874, 2012.

Stephenson, S. R., Smith, L. C., Brigham, L. W., and Agnew, J. A.: Projected 21st-century changes to Arctic marine access, Climatic Change, 118, 885-899, https://doi.org/10.1007/s10584012-0685-0, 2013.

Stroeve, J., Holland, M. M., Meier, W. Scambos, T., and Serreze, M.: Arctic sea ice decline: Faster than forecast, Geophys. Res. Lett., 34, 1-5, https://doi.org/10.1029/2007GL029703, 2007.

Stroeve, J. C., Serreze, M. C., Holland, M. M., Kay, J. E., Maslanik, J., and Barrett, A. P.: The Arctic's rapidly shrinking sea ice cover: a research synthesis, Climatic Change, 110, 1005-1027, https://doi.org/10.1007/s10584-011-0101-1, 2012.

Swart, N. C., Fyfe, J. C., Hawkins, E., Kay, J. E., and Jahn, A.: Influence of internal variability on Arctic sea-ice trends, Nat. Clim. Change, 5, 86-89, https://doi.org/10.1038/nclimate2483, 2015.

Tietsche, S., Notz, D., Jungclaus, J. H., and Marotzke, J.: Recovery mechanisms of Arctic summer sea ice, Geophys. Res. Lett., 38, 1-4, https://doi.org/10.1029/2010GL045698, 2011.

Wang, M. and Overland, J. E.: A sea ice free summer Arctic within 30 years?, Geophys. Res. Lett., 36, L07502, https://doi.org/10.1029/2009GL037820, 2009.

Wang, M. and Overland, J. E.: A sea ice free summer Arctic within 30 years: An update from CMIP5 models, Geophys. Res. Lett., 39, L18501, https://doi.org/10.1029/2012GL052868, 2012.

Wang, M. and Overland, J. E.: Projected future duration of the seaice-free season in the Alaskan Arctic, Prog. Oceanogr., 136, 5059, https://doi.org/10.1016/j.pocean.2015.01.001, 2015.

Wernli, H. and Papritz, L.: Role of polar anticyclones and midlatitude cyclones for Arctic summertime sea-ice melting, Nat. Geosci., 11, 108-113, https://doi.org/10.1038/s41561-017-0041$0,2018$.

Woodgate, R. A., Weingartner, T. J., and Lindsay, R.: Observed increases in Bering Strait oceanic fluxes from the Pacific to the Arctic from 2001 to 2011 and their impacts on the Arctic Ocean water column, Geophys. Res. Lett., 39, L24603, https://doi.org/10.1029/2012GL054092, 2012.

Zhao, J., Barber, D., Zhang, S., Yang, Q., Wang, X., and Xie, H.: Record Low Sea-Ice Concentration in the Central Arctic during Summer 2010, Adv. Atmos. Sci., 35, 106-115, https://doi.org/10.1007/s00376-017-7066-6, 2018. 